\title{
PENGUATAN PENDIDIKAN POLITIK DALAM MENINGKATKAN SIKAP BELA NEGARA SISWA DI SMA NEGERI 3 MALANG
}

\author{
Fitrianur Widya Ningrum, Trisakti Handayani, M. Mansur Ibrahim \\ FKIP Universitas Muhammadiyah Malang \\ Email : fitrianurwidyan@gmail.com
}

\begin{abstract}
ABSTRAK
Pendidikan politik merupakan usaha yang dilakukan terus-menerus dan berproses untuk meningkatkan pengetahuan politik agar dapat berpartisipasi secara optimal untuk menyelesaikan masalah di bidang politik. Saat ini, praktik dan pemahaman mengenai pendidikan politik masih lemah. Hal itu dikarenakan, merosotnya nilai karakter pada peserta didik serta timbulnya sikap acuh yang disebabkan oleh arus perkembangan jaman dan teknologi yang canggih. Oleh karena itu, pendidikan politik perlu dimaksimalkan kembali agar dapat membina dan mengarahkan peserta didik untuk dapat memahami hak dan tanggungjawabnya sebagai warga negara Indonesia. Penelitian ini bertujuan untuk mengetahui pelaksanaan penguatan pendidikan politik dalam meningkatkan sikap bela negara siswa di SMA Negeri 3 Malang, faktor penghambat dan pendukung beserta solusi untuk mengatasi hambatan yang muncul. Pengumpulan data diperoleh melalui observasi secara langsung dan mendokumentasi hal-hal yang berkaitan dengan penelitian serta wawancara mendalam kepada sepuluh informan. Data dianalisis secara kualitatif yang terdiri dari empat alur kegiatan yaitu pengumpulan data, reduksi data, penyajian data dan penarikan kesimpulan. Serta, tahapan terakhir ialah keabsahan data menggunakan triangulasi teknik. Hasil penelitian ini menunjukan bahwa penguatan pendidikan politik dalam meningkatkan sikap bela negara siswa di SMA Negeri 3 Malang dalam pelaksanaannya dapat meningkatkan sikap bela negara bagi anggota OSIS, dan anggota Paskibra. Hal ini dapat dilihat dari kegiatan yang dilakukan dan hasil yang didapatkan setelah mengikuti kegiatan tersebut, sehingga mendorong mereka untuk menjalankan hak nya sebagai warga negara yang bersedia membela NKRI. Faktor penghambat berupa adanya anggota OSIS dan anggota Paskibra yang kurang bisa memanejemen waktu dan kesulitan mendapatkan dispensasi dari guru. Faktor pendukungnya berupa dukungan dari sekolah, motivasi diri, komunikasi yang baik antar anggota, dan keteladanan dari guru.
\end{abstract}

Kata Kunci : Pendidikan Politik, Sikap Bela Negara.

\begin{abstract}
Political education is an ongoing effort and processes to increase political knowledge in order to participate optimally to solve political problems. At present, practices and understanding of political education are still weak. This is because, the decline in character values in students and the emergence of indifference caused by the current development of sophisticated times and technology. Therefore, political education needs to be maximized again in order to foster and direct students to understand their rights and responsibilities as Indonesian citizens. This study aims to find out the implementation of strengthening political education in improving the defense attitudes of students in Senior High School 3 Malang, inhibiting and supporting factors along with solutions to overcome obstacles that arise. Data collection was obtained through direct observation and documenting matters relating to research and in-depth interviews with ten informants. The data were analyzed qualitatively consisting of four activities, namely data collection, data reduction, data presentation and conclusion drawing. And, the last stage is the validity of the data using technical triangulation. The results of this study indicate
\end{abstract}


that the strengthening of political education in enhancing the state of defense of students in Senior High School 3 Malang in its implementation can improve state defense for members of the Student Council, and members of Flag Hoisting Troop. This can be seen from the activities carried out and the results obtained after participating in these activities, thus encouraging them to exercise their rights as citizens who are willing to defend the Republic of Indonesia. The inhibiting factor is the existence of student council members and Flag Hoisting Troop members who are not able to manage time and have difficulty getting dispensation from the teacher. Supporting factors include support from school, self motivation, good communication between members, and exemplary from the teacher.

Keywords: Political Education, Defend the Country.

\section{PENDAHULUAN}

Pendidikan politik sangatlah penting, bagi kalangan pelajar dan atau lembaga pendidikan formal. Dikarenakan, pendidikan politik dapat menambah pengetahuan siswa kemudian mengembangkan dan menjadikannya bekal ketika menjadi generasi penerus di masa yang akan datang. Ketika siswa memahami dan mengerti secara keseluruhan apa itu pendidikan politik dan bagaimana penerapannya, maka mereka mampu menjadi generasi penerus yang cerdas berjiwa nasionalisme dan patriotisme yang tinggi. Sehingga, dapat menjadikan negara Indonesia menjadi lebih baik lagi.

Menurut UU Nomor 3 Tahun 2002 tentang Pertahanan Negara dijelaskan bahwa upaya bela negara adalah sikap dan perilaku warga negara yang dijiwai oleh kecintaannya kepada Negara Kesatuan Republik Indonesia yang berdasarkan Pancasila dan UUD 1945 dalam menjamin kelangsungan hidup bangsa dan negara. Upaya bela negara, selain sebagai kewajiban dasar manusia, juga merupakan kehormatan bagi setiap warga negara yang dilaksanakan dengan penuh kesadaran, tanggungjawab, dan rela berkorban dalam pengabdian kepada negara dan bangsa. Kemudian, yang menjadi landasan hukum bagi pendidikan politik adalah landasan ideologis yaitu
Pancasila, landasan konstitusional yaitu UUD 1945 dan landasan historis yaitu Sumpah Pemuda 28 Oktober dan Proklamasi Kemerdekaan 17 Agustus 1945. Landasan ini merupakan landasan konseptual pokok pendidikan politik yang disertai landasan kesejarahan. Hal ini penting, karena warga negara terutama siswa kaum terpelajar harus mengetahui sejarah perjuangan bangsa, agar memiliki jiwa, semangat, dan nilai-nilai perjuangan.

Landasan filosofis pendidikan digunakan sebagai ukuran melakasanakan studi dan praktek pendidikan. Melalui studi pendidikan kita memperoleh pemahaman dan gagasan mengenai landasan-landasan pendidikan, yang akan dijadikan ukuran dalam praktek pendidikan. Maka dari itu, landasan filosofi pendidikan sebagai hasil studi pendidikan tersebut, dapat dijadikan ukuran untuk memenuhi studi pendidikan yang bersifat filsafiah, yaitu pendekatan yang lebih spekulatif, normatif dan komprehensif. Hal ini tentunya akan berlaku bagi pendidikan politik bagi siswa selaku siswa, (Suyitno, 2009).

Berdasarkan observasi, hasil wawancara dan studi pendahuluan dengan guru Pendidikan Kewarganegaraan SMA Negeri 3 Malang bapak Rohmatul Adib, pendidikan politik di lingkup sekolah saat masih lemah, di karenakan merosotnya nilai-nilai karakter pada siswa serta 
timbulnya sikap acuh yang juga disebabkan oleh adanya arus perkembangan dan teknologi yang canggih. Oleh karena itu, pendidikan politik perlu dimaksimalkan kembali agar dapat membina dan mengarahkan peserta didik untuk dapat memahami hak dan tanggungjawabnya sebagai warga negara Indonesia. Pendidikan politik bertujuan untuk membentuk dan menumbuhkan kesadaran dan orientasi politik peserta didik. Kemudian, mampu memberikan partisipasinya dalam aspek kesadaran berbangsa bernegara, pembentukan karakter dan meningkatkan rasa nasionalisme dan patriotisme.

Perlu adanya dorongan untuk menguatkan kembali kesadaran dan orientasi politik siwa agar dapat meningkatkan sekaligus menguatkan sikap bela negara dan nilai-nilai karakter. Dorongan tersebut dapat didapatkan dari luar maupun dalam lingkup sekolah seperti, ekstrakulikuler yang ada disekolah, organisasi sekolah, forum diskusi dan debat maupun gerakan kepramukaan. Penulis memilih lokasi di SMA Negeri 3 Malang di karenakan, hasil observasi awal mengenai pendidikan politik banyak melibatkan kegiatan seperti, kepramukaan, Paskibra, dan OSIS. Kegiatan tersebut diwarnai dengan sikap bela negara, nasionalisme dan penuh dengan karakter serta gaya kepemimpinan peserta didik yang beranekaragam, terlebih SMA Negeri 3 merupakan sekolah yang peserta didiknya berprestasi dalam bidang akademik maupun bidang non akademik seperti kegiatan ekstrakulikuler.

Pendidikan politik erat kaitannya dengan bela negara. Karena, pendidikan politik memberikan pedoman kepada generasi muda Indonesia guna meningkatkan kesadaran kehidupan berbangsa dan bernegara berdasarkan Pancasila dan UUD NRI 1945 sebagai salah satu usaha untuk membangun manusia Indonesia seutuhnya, yakni bermoral dan berkarakter (Wibowo, 2013).

Berdasarkan latar belakang permasalahan tersebut dapat dirumuskan beberapa rumusan masalah sebagai berikut : (1) Bagaimana pelaksanaan penguatan pendidikan politik dalam meningkatkan sikap bela negara siswa di SMA Negeri 3 Malang? (2) Apa faktor penghambat dan pendukung dalam usaha penguatan pendidikan politik untuk meningkatkan sikap bela negara siswa di SMA Negeri 3 Malang? (3) Bagiamana solusi mengatasi hambatan yang muncul dalam usaha penguatan pendidikan politik untuk meningkatkan sikap bela negara siswa di SMA Negeri 3 Malang?

\section{METODE}

Penelitian ini menggunakaan jenis penelitian kualitatif dan menggunakan pendekatan fenomenologi. Menurut Sugiyono (2015) metode penelitian kualitatif adalah metode penelitian yang berlandaskan pada filsafat positivisme, digunakan untuk meneliti pada kondisi obyek yang alamiah, (sebagai lawannya adalah eksperimen) dimana peneliti adalah sebagai instrument kunci, pengambilan sampel sumber data dilakukan secara purposive, teknik penggabungan dengan trianggulasi (gabungan), analisis data bersifat induktif/kualitatif, dan hasil penelitian kualitatif lebih menekankan makna dari generalisasi.

Kemudian, menurut Kuswarno (2009) pendekatan fenomenologi adalah fakta yang disadari dan masuk ke dalam pemahaman manusia. Fenomenologi merefleksikan pengalaman langsung manusia, sejauh pengalaman itu secara intensif berhubungan 
dengan suatu objek. Pada dasarnya fenomenologi mempelajari struktur tipetipe kesadaran, yang terentang dari persepsi, gagasan, memori, imajinasi, emosi, hasrat, kemauan, sampai tindakan, baik itu tindakan sosial maupun dalam bentuk bahasa. Oleh sebab itu, peneliti memilih jenis penelitian kualitatif dan pendekatan fenomenologi untuk memudahkan peneliti dalam menganalisis fenomena yang terjadi mengenai gejala, sikap dan pandangan kelompok maupun peseorangan terhadap kegiatan-kegiatan dan aktivitas sosialnya yang terjadi di lapangan.

Penelitian ini dilaksanakan di SMA Negeri 3 Malang. Peneliti memilih SMA Negeri 3 Malang sebagai lokasi penelitian dikarenakan di SMA Negeri 3 Malang merupakan tempat yang baik dan strategis dalam melakukan penelitian, dan merupakan salah satu sekolah di Malang yang selalu menanamkan sikap bela negara dan nasionalisme melalui kegiatan ekstrakulikulernya serta meningkatkan prestasi akademik maupun non akademik. Hal tersebut yang membuat peneliti tertarik untuk meneliti di SMA Negeri 3 Malang.

Waktu penelitian merupakan waktu di mana penelitian ini dilakukan mulai dari penyusunan tugas akhir, permohonan izin hingga selesai penulisan tugas akhir penelitian. Proses penyelesaian dalam penelitian ini memerlukan waktu kurang lebih 5 bulan yakni dilakukan pada akhir bulan februari sampai bulan juli 2018.

\section{HASIL DAN PEMBAHASAN}

Berdasarkan hasil penelitian dan data yang telah diuraikan di atas akan dijelaskan lebih lanjut mengenai pembahasan yang mengacu pada rumusan masalah penelitian. Adapun pembahasannya adalah sebagai berikut:

\section{Pelaksanaan Pendidikan Politik dalam Meningkatkan Sikap Bela Negara}

Berdasarkan hasil penelitian yang telah diuraikan pada pembahasan sebelumnnya, pelaksanaan pendidikan politik dalam meningkatkan sikap bela negara di SMA Negeri 3 Malang yang di lakukan oleh anggota OSIS dan anggota Paskibra tersebut telah memahami pengertian pendidikan politik dan praktiknya dalam kehidupan sehari-hari, baik di sekolah maupun di dalam kehidupan bermasyarakat. Anggota OSIS dan anggota Paskibra tersebut memiliki semangat nasionalisme dan kebangsaan dan ketika di hadapkan oleh berbagai masalah yang menimpa bangsa secara otomatis menunjukan sikap bela negaranya. Karena, anggota OSIS dan anggota Paskibra tersebut telah diajarkan rasa kebersamaan, kedisiplinan dan tanggungjawab. Hal tersebutlah yang mendorong anggota OSIS dan anggota Paskibra untuk selalu menuntaskan pekerjaan dan tanggungjawabnya baik sebagai pelajar, warga negara dan sebagai siswa yang aktif dalam berorganisasi. Berkaitan dengan Rahman (2017) kesadaran bela negara ialah kesediaan untuk berbakti dan setia pada negara dan kesediaan berkorban membela negara. Tindakan dalam membela negara itu sangat luas, mulai dari yang paling halus, hingga yang paling keras. Mulai dari hubungan baik sesama warga negara sampai bersama-sama memberi aksi untuk mencegah ancaman nyata musuh bersenjata, baik dari luar negeri mapun dalam negeri.

Anggota OSIS dan anggota Paskibra ketika melaksanakan pendidikan politik dalam meningkatkan sikap bela negara ini dilakukan melalui kegiatan-kegiatan seperti; diskusi yang berkaitan tentang organisasi 
internalnya dan diskusi mengenai permaslahan yang mencuat ke publik yang patut untuk dibicarakan, latihan rutin anggota Paskibra, bakti sosial, pelaksanaan upacara bendera senin, pelaksanaan upacara HUT Kemerdekan RI, debat event yang dilakukan oleh anggota OSIS, mengikuti sosialiasi yang diselenggarakan oleh KPU dan Lembaga Pemerintahan lain secara resmi dan memaksimalkan kepemimpinan yang di emban ketika ada event serta kepememimpinan sebagai ketua OSIS maupun ketua Paskibra. Kemudian, kegiatan yang di lakukan dan diikuti tersebut memberikan dampak positif bagi masyarakat sekitar, sekolah dan untuk siswa itu sendiri.

Bersaman dengan hal di atas anggota OSIS dan anggota Paskibra ini lebih unggul dibandingkan dengan siswa yang lain. Anggota OSIS dan anggota Paskibraka lebih peka terhadap permasalahan yang terjadi di lingkungan sekitar, lebih sadar akan hak dan kewajibannya sebagai warga negara dan sebagai pelajar. Kemudian, jika dihadapkan oleh berbagai rutinitas yang padat anggota OSIS dan anggota Paskibraka mampu memanajemen waktunya dengan baik. Selain itu juga dapat mengerjakan tugas sekolah dan perkerjaan rumah dengan baik.

Perbedaan penelitian ini dari penelitian terdahulu ialah dalam penelitian yang dilakukan saya selaku peneliti menggunakan pendidikan politik sebagai sarana dan alat untuk tercapainya karakter dan sikap bela negara siswa terhadap negaranya. Kemudian, siswa dapat memahami dan mengerti secara keseluruhan apa itu pendidikan politik dan bagaimana penerapannya. Sedangkan penelitian terdahulu, menjelaskan bagaimana sosialisasi politik dan agen-agen pendidikan politik. menggunakan penelitian di dalam kelas. Oleh karena itu, perbedaan yang paling menonjol ialah peneliti tidak mengambil unsur penerapan pendidikan politik di dalam kelas. Peneliti hanya menggunakan unsur di luar kelas seperti kegiatan ekstrakulikuler, diskusi bebas atau kebebasan berpendapat dan gaya kepemimpinan siswa SMA Negeri 3 Malang.

\section{Faktor Penghambat dan Pendukung dalam Usaha Penguatan Pendidikan Politik untuk Meningkatkan Sikap Bela Negara}

Berdasarkan hasil analisis data yang telah diperoleh dan diuraikan mengungkapkan bahwa anggota OSIS dan anggota Paskibra ketika melaksanakan pendidikan politik dalam meningkatkan sikap bela negara mendapatkan hambatan yang dapat diklasifikasikan menjadi dua bentuk yaitu faktor hambatan dari dalam dan dari luar. Faktor hambatan dari dalam yakni, dari anggota itu sendiri beberapa ada yang kurang bisa memanejemen waktu dan adanya miss komunikasi, kesulitan mendapatkan dispensasi dari guru, dan kebijakan sekolah yang ketat. Kemudian, faktor dari luar yaitu orangtua ada yang paham dan mengerti akan kegiatan OSIS dan Pakibra ada juga yang tidak paham dan takutnya mengganggu pelajaran, ada juga dari masyarakat sekitar kalau ada kegiatan-kegiatan yang mengganggu ketika ada suara-suara jika ada kegiatan malam.

Begitu pula berdasarkan hasil analisis data yang telah diperoleh dan diuraikan mengungkapkan bahwa anggota OSIS dan anggota Paskibraka ketika melaksanakan pendidikan politik dalam meningkatkan sikap bela negara mendapatkan dukungan dari dalam dan dari luar. Dukungan yang didapatkan anggota OSIS dan Paskibraka dari dalam yakni adanya dukungan dari sekolah, motivasi diri, komunikasi yang 
baik dan sejalan sehingga kegiatan berjalan dengan lancar, dukungan dari guru berupa pemberian dispensasi dan motivasi, fasilitas yang diberikan oleh sekolah, alumni yang turut hadir ketika ada kegiatan, komitmen dari peserta yang mengikuti kegiatan dan acara, kerjasama antar anggota dan panitia, mendapat persetujuan dari sekolah, pendampingan dan kontrol dari sekolah. Lalu, dukungan yang didapatkan anggota OSIS dan Paskibra dari luar yakni adanya sponsor kegiatan dan acara, diberikan ijin oleh orangtua ketika mengikuti kegiatan, adanya dukungan dan motivasi dari teman terdekat dan orangtua, juga masyarakat sekitar yang turut berpartisipasi ketika ada kegiatan yang berlangsung.

\section{Solusi Mengatasi Hambatan yang Muncul dalam Usaha Penguatan Pendidikan Politik untuk Meningkatkan Sikap Bela Negara}

Berdasarkan data yang diperoleh sejauh ini solusi yang diberikan oleh guru PPKn, waka kesiswaan, kepala sekolah, anggota OSIS dan anggota Paskibra untuk mengatasi hambatan yang muncul ialah bapak dan ibu guru memberikan semangat dan dorongan agar siswa yang tidak konsisten bisa lebih konsisten lagi dan semangat dalam menjalani kegiatan ekstrakulikuler seperti OSIS dan Paskibra. Kemudian, penting adanya support dari sekolah dan peran leader yakni kepala sekolah, koordinasi dengan kesiswaan untuk menghimbau bapak ibu guru dalam memberikan dispen, sehingga guru yang ditinggalkan bisa menerima kebijakan yang ada di sekolah. Termasuk orangtua diberikan pemberitahuan-pemberitahuan terkait kegiatan yang dilaksanakan sehingga dapat ijin dari orang tua. Serta, di masyarakat kita juga meminta ijin terkait kegiatan yang mengganggu seperti kebisingan dan lain sebagainya. Setelah itu solusi yang lain adalah mempertahankan kepercayaan yang diberikan oleh guru ketika memberikan dispensasi, merancang dari awal apa yang harus dilakukan selama masa jabatan satu tahun kedepan dan jangan sampai ada misscomunication. Serta, menyesuaikan dengan sarana yang ada. Lalu, solusi lainnya yakni keteladanan guru. Jika guru yang menjadi teladan untuk siswa maka, secara otomatis langsung diterapkan oleh siswa tersebut dan juga guru-guru harus update agar komunikasi bisa berjalan baik dan lancar. Sehingga, literasi guru itu dapat sejalan dengan digital dan budaya.

\section{SIMPULAN}

Berdasarkan hasil penelitian dan pembahasan pada bab sebelumnya, dapat disimpulkan sebagai berikut :

a) Penguatan pendidikan politik dalam meningkatkan sikap bela negara siswa di SMA Negeri 3 Malang dalam pelaksanaannya ini dapat meningkatkan sikap bela negara bagi anggota OSIS, dan anggota Paskibra. Hal ini dapat dilihat dari kegiatan yang dilakukan dan hasil yang didapatkan setelah mengikuti kegiatan tersebut dan mendorong mereka untuk menjalankan hak nya sebagai warga negara yang bersedia membela negara Kesatuan Republik Indonesia. Anggota OSIS dan anggota Paskibra memiliki sikap dan gaya kepemimpinan yang berkarakteristik, bertanggungjawab, memiliki jiwa nasionalisme dan patriotisme yang tinggi. Kemudian juga, secara otomatis anggota OSIS dan anggota Paskibra memiliki nilai lebih dibanding siswa yang lain. Disamping itu, kegiatan ekstrakulikuler Pramuka yang tidak aktif telah digantikan dengan adanya kegiatan Bedhol Bhawikarsu yang dianggap memiliki nilai-nilai sama 
dengan kepramukaan dan terdapat sikap budi pekerti bagi siswa yang mengikuti kegiatan tersebut.

b) Faktor penghambat dan pendukung dalam usaha penguatan pendidikan politik untuk meningkatkan sikap bela negara terbagi dalam dua bentuk, yang pertama faktor penghambat dari dalam dan dari luar, yang kedua faktor pendukung dari dalam dan dari luar. Faktor penghambat dari dalam yakni berupa dari anggota itu sendiri beberapa ada yang kurang bisa memanejemen waktu dan kesulitan mendapatkan dispensasi dari guru. Faktor penghambat dari luar yakni orangtua anggota OSIS dan Paskibraka ada yang tidak paham mengenai kegiatan yang dilakukan oleh anaknya dan takutnya mengganggu pelajaran, dan juga dari masyarakat sekitar yang merasa terganggu ketika ada kegiatan-kegiatan dan suara-suara saat kegiatan malam. Sedangkan faktor pendukung dari dalam yakni berupa dukungan dari sekolah, motivasi diri, komunikasi yang baik dan sejalan sehingga kegiatan berjalan dengan lancar, dukungan dari guru berupa pemberian dispensasi dan motivasi, dan fasilitas yang diberikan oleh sekolah. Lalu, faktor pendukung dari luar yakni berupa sponsor kegiatan dan acara, adanya ijin oleh orang tua ketika mengikuti kegiatan, dan adanya dukungan dari teman terdekat.

c) Solusi yang diambil oleh anggota OSIS dan Paskibra dalam mengatasi hambatan yang muncul ialah bapak dan ibu guru memberikan semangat dan dorongan agar siswa yang tidak konsisten bisa lebih konsisten lagi dan semangat dalam menjalani kegiatan, koordinasi dengan kesiswaan untuk menghimbau bapak ibu guru dalam memberikan dispensai, sehingga guru yang ditinggalkan bisa menerima kebijakan yang ada di sekolah. Kemudian, orangtua diberikan pemberitahuan-pemberitahuan terkait kegiatan yang dilaksanakan sehingga dapat ijin dari orang tua dan juga di dalam masyarakat juga meminta ijin terkait kegiatan yang mengganggu seperti kebisingan dan lain sebagainya.

\section{DAFTAR PUSTAKA}

Kuswarno, Engkus. 2009. Fenomenologi. Bandung: Widya Padjajaran. (Online), (https://www.academia.edu/ 16688487/Pendekatan- pendekatan_ dalam_penelitian_Kualitatif), diakses 06 Desember 2017.

Permendikbud Nomor 63 Tahun 2014 tentang Pendidikan Kepramukaan Sebagai Ekstrakulikuler Wajib. Kementrian Agama. (Online), (http:// simpuh.kemenag.go.id/regulasi/ permendikbud_63_14_lampiran01. pdf) diakses 8 Agustus 2018).

Rahman, Abd. 2017. Pendidikan Kewarganegaraan di Perguruan Tinggi. Jakarta: Celebes Media Perkasa.

Sugiyono. 2015. Metode Penelitian Pendidikan; Pendekatan Kuantitatif, Kualitatif, dan $R \& D$. Bandung: Alfabeta.

Suyitno. 2009. Landasan Filosofis Pendidikan, (Online), (http:// file.upi.edu/Direktori/FIP/ JUR._PEDAGOGIK/1950090 8198 1011-Y_SUYITNO/LANDASAN_ FILOSOFIS_PENDIDIKAN_ DASAR.pdf), diakses 07 Desember 2017.

Wibowo, Puji. 2013. Pelaksanaan Pendidikan Politik di Sekolah, (Online),

(http://repository.ump.ac.id/6129/3/ Puji\%20Wibowo\%20Bab\%20II.pdf) diakses 01 Februari 2018. 